Again, the University has to thank the late Mr. H. H. Wills both for the estate and buildings. The erection of the physical laboratories on this commanding site has been progressing slowly but steadily, and they will be ready for occupation in about eighteen months. In this case also it would appear that provision is being made for its full growth for at least a generation, but the history of the chemical department leads any such statement to be received witl caution.

The Royal Fort estate is beautifully situated on one of the highest points in Bristol ; except for a portion now being used as an extension of the Botanical Garden and that occupied by the new physics buildings, no other sites have yet been earmarked, but it contains space for other departments which are certain to be wanted in the future, and these can be built without destroying the main features of the charming eighteenthcentury residence and garden which forms a large portion of the estate, and so delighted the visitors who attended the garden party held there on June 9 after the opening ceremony.

Another delightfully situated eighteenth - century residence, Clifton Hill House, was presented to the University in 1909 as a hostel for women students, and was extended in I9I I by the addition of the adjoining Callender House. At present the men are accommodated in Mortimer House and Canynge Hall, but in the near future a magnificent hostel is to be erected by Sir George Wills on the far side of the Downs on an estate presented to the University by Mr. H. H. Wills close to the athletic grounds at Coombe Dingle. Finally, the students and staff are fortunate in possessing a wellknown landmark in the city, the Victoria Rooms, in close proximity to the University, where their Majesties had lunch on June 9. These fine buildings have been bought, endowed, entirely modified internally, and presented to the University for the purpose of a Club, by the same generous donor whose name will be for ever remembered in the city of Bristol.

\title{
Metal Resources and the Constitution of the Earth.
}

SPECULATION concerning the origin of ore deposits has been for many years, and is at the present time, dominated by the school of theorists who attribute a proximate and direct igneous origin not only to igneous segregations, contact deposits, and the metalliferous vein-deposits immediately associated with igneous intrusions, but to metalliferous veins generally. The grip attained by this theory is such that only rarely do authors of papers take a larger and more comprehensive view of either the possibilities or the actual facts of vein-formation. The extent to which the mind of the average worker is obsessed by the igneous theory is shown by the tendency to apply it in cases where it seems almost certainly inapplicable. In bedded iron-ores, sedimentary lead- and zinc-ores, and even petroleum, the igneous enthusiast sees clear evidence of metalliferous solutions and vapours rising through the earth's crust and effecting mineralisation at all levels on their way to the surface.

When igneous rocks are present anywhere within reasonable reach of metalliferous deposits, the igneous enthusiast is of course particularly happy. These igneous rocks may be miles away, but what does that matter? They may be entirely absent from the surface of a whole region; but that does not disturb his cheerful faith that somewhere the barysphere is bubbling. Indeed, at even shallower depths than the barysphere, are there not the seething metalliferous cauldrons of the magmasphere? The fact that both are well out of the way and far beyond the reach of observation comforts him rather than stirs his doubts, for on this account the barysphere and magmasphere are even more useful as a basis c $f$ speculation than they would be otherwise.

The notion that metalliferous veins have been deposited by solutions and vapours escaping from the barysphere was first made attractive by Posepny, and was freely adopted by students of ore genesis, partly on account of its simplicity and plausibility, and partly because it was regarded as the only alternative to the theory of lateral secretion, which had been found wanting. Though simple and plausible, however, it is almost certainly false, and the geological case against it was very fairly stated by Le Conte, in his contribution to the discussion on Posepny's paper. In recent years the igneous theory has gradually assumed a form in which it is more acceptable to geologists, the seat of the juvenile metals being fixed, not in the barysphere, but in ordinary rock-magmas originating at comparatively shallow depths. In this form the igneous theory is just as simple and plausible as it was in the barysphere form, and it is more difficult to refute, although, as applied to most deposits, it is probably nearly as false ; but if so, whence came the metals of the vein deposits and contact deposits so often associated with igneous intrusions?

This problem, which is not only interesting in itself on purely scientific grounds, but is also important in its bearing on metal resources, was considered by Sir Thomas Holland in his presidential address at the annual general meeting of the Institution of Mining and Metallurgy on April 23. The ground he took was the contrast between the small percentages of the less abundant metals in the earth's crust as a whole, and their percentages in ore deposits. Taking the average composition of igneous rocks calculated by Clarke and Washington (see NAture, Aug. 19, 1922, p. 254) as the best data available, he pointed out that, according to these data, elements formerly regarded as rare, such as zirconium and cerium, are more abundant in the earth's crust as a whole than are the familiar base metals copper, zinc, lead, and tin. Again, nickel, which is prcduced in comparatively small amounts, is ten times as abundant as lead and some hundred times as abundant as tin.

Adopting the now apparently well-established view that the earth has a large core of nickel-iron, which is surrounded by silicate-rock shells decreasing in basicity from an inner shell of peridotite to an outer one of granite-gneiss, Sir Thomas Holland states that the natural home of the heavier metals is deep down in the core, and asks: "How then do they get to the surface

NO. 2902, VOL.. I I 5 ] 
at all ? Have they, since the earth settled down after Archæan times, been brought up in any appreciable quantity from great depths, or are we now dependent on the mere lateral segregation of small traces originally scattered residually through the outermost crust and left as the result of an imperfect gravitational adjustment when the earth passed from the molten to the solid state?"

Of the two rival theories, namely (I) that the metals have been brought from great depths in igneous eruptives, and (2) that the metalliferous deposits have been formed by the segregation of materials originally disseminated through comparatively superficial rocks, he remarks that they need not be mutually exclusive, and that they may be complementary; but after a consideration of the relative significance and merits of the two theories, he infers that only a small fraction of ore deposits show signs of transport from great depths, while the majority of those that are workable seem to be the result of simple lateral segregation, and even a large proportion of these are probably derived by segregation processes in the uppermost layers.

This view, which is probably the truth of the matter, so far as can be judged from the geodynamical evidence at present available, has an important bearing on the problem of the duration of supplies of metals. Supplies of lead, tin, zinc, and copper are likely to be exhausted long before those of coal and iron, and Sir Thomas Holland thinks it unjustifiable to take an optimistic view of the possibilities as regards aluminium, for bauxite deposits are few and small, and it remains to be proved that the metallurgical treatment of aluminium silicates is economically feasible.
In the concluding portion of his address he made some interesting remarks on the present condition of geology as a science. He clearly agrees with the editor of the New Yark Engineering and Mining Joumal-Press, who told us recently that geological science is in the doldrums. Geological science, says Sir Thomas, is at present experiencing " a reposeful interlude "; it is indulging a "siesta." In his opinion the geological imago is more likely to emerge from its chrysalis stage at the meetings of the Institution of Mining and Metallurgy than at the meetings of the Geological Society. It would perhaps be wiser to expect any development that may affect geology as a science to be less sudden and spectacular than the emergence of an imago. The development is more likely to be gradual. Nothing could contribute more effectively towards the desired change than regular and joint meetings for discussion by the various societies interested. Is it too much to expect that the Geological Society, the Mineralogical Society, and the Institution of Mining and Metallurgy will one day establish permanent joint sessions and meet periodically, even if infrequently, to discuss topics of common interest? There is much uncultivated common ground between them Dynamical geology, petrology, and mineral genetics require to be welded together into a scientific whole. By meeting periodically to promote the attainment of this end, each of the societies concerned would, while widening its own outlook, help forward the development of science. Now or never is the time to make this move, when three such able and intimate colleagues as Sir Thomas Holland, Prof. Watts, and Dr. Evans occupy the presidential chairs of the three societies chiefly concerned.

T. C.

\title{
The Discovery of Benzene.
}

\author{
By Prof. Jocelyn F. Thorpe, C.B.E., F.R.S.
}

$\mathrm{I}^{\mathrm{T}}$ is a fact not generally known that Faraday's early work at the Royal Institution was mainly of a purely chemical character and that it was not until later, about I83I, that he took up the study of electricity and magnetism, the branch of physics in which his more famous discoveries were made and with which his name is usually associated in the public mind. It is evident, of course, that this bent towards the chemical side of science was determined by his early association with Sir Humphry Davy, for Faraday has left abundant records illustrating the influence Davy's lectures and personality had on him. He seems to have first attended these lectures in 1812 when, as a youth of twenty-one, he was still serving as apprentice to Mr. George Riebau, a bookseller in Blandford Street; later he sent Davy a copy of the notes he had taken, together with a letter in which he expressed a wish to abandon trade and adopt a scientific career. It was well for posterity that this letter did not meet the same fate as that of a similar one sent to Sir Joseph Banks, then president of the Royal Society, which remained unanswered; for Davy sent a kindly and encouraging reply which not only led to an interview between them, but afterwards to the offer of a post as assistant at the Royal Institution, the salary being $25 \mathrm{~s}$. a week with the use of two rooms at the top of the house; the minute of the Managers recording this appointment is dated March I, I8I3. Faraday did not, however, remain long at the Institution, for on Sir Humphry Davy relinquishing his appointment as professor of chemistry in 1813 , Faraday accompanied him as secretary during a tour through Europe which occupied the next eighteen months.

It appears that Faraday had arranged with Davy prior to the tour that his post at the Royal Institution should be kept open for him, and to this he returned in April 1815 , being in the following month appointed "Assistant in the laboratory and mineralogical collection and superintendent of the apparatus at a salary of 3 os. a week," apartments also being granted him. From this date onward until the end of what may be termed the first period, which closed with his illness in 1830 , his work was almost entirely of a chemical character. His illness seems to have prevented him from doing active work for nearly four years, and thereafter he devoted his genius to the development of electricity and magnetism, and seems to have abandoned all work on the purely chemical side. Nevertheless, during the earlier period he made many important discoveries, for it seemed impossible for 